\title{
Project Based - Content Language Integrated Learning (Clil) at Mathematics Department Universitas Lampung
}

\author{
Hery Yufrizal ${ }^{1}$, Huzairin $^{1} \&$ Basturi Hasan ${ }^{1}$ \\ ${ }^{1}$ Universitas Lampung, Indonesia \\ Correspondence: Hery Yufrizal, Universitas Lampung, Indonesia. E-mail: heryyufrizal@gmail.com
}

Received: June 1, 2017 Accepted: August 6, 2017 Online Published: August 11, 2017

doi: 10.5539/elt.v10n9p131ＵRL: http://doi.org/10.5539/elt.v10n9p131

\begin{abstract}
This article aims at exploring wether project based content language integrated learning (CLIL) has s significant effect on the oral capability of students of science department of the University of Lampung. The number of students invoved in this study was 88 students. Quantitative data was obtained from the value of students' English proficiency before and after CLIL model application. While the qualitative data was obtained from the output of language produced by students during the learning process took place.

The results showed that project based CLIL English language course in Mathematics study program the faculty of teaching and education, the University of Lampung could work effectively. This is evident from the implementation of the whole program activities, from the implementation of the formation of groups, students work in groups to finish the project, group presentation activities, personal presentations and students' responses to all activities.
\end{abstract}

Keywords: content language integrated learning (CLIL), project based, mathematics study program

\section{Introduction}

English courses are compulsory subjects for university students in Indonesia. The purpose of learning English in each college institution is different. Similarly, in every department or course. In general, the purpose of learning English is to provide additional skills so that students are able to apply it in a communicative, oral and written. The topic of study is focused on the aspects of language skills (listening, speaking, reading, and writing), including the study of vocabulary, diction and structure related to the use of English in the community (Faculty of Teaching and Education Universitas Lampung, 2014).

The need for mastery of English in the future becomes a challenge for higher education institution as one the producers for human resources. If the higher education institution wanted to win the competition in the world, it must equip its graduates with sufficient English language skills. In addition, for students, having sufficient English skills will be very helpful in completing the tasks of college, especially in reading text books in English. To address all the above challenges, it is necessary to improve the teaching of English for non-English Study Program students by using a more appropriate design and teaching approach by placing the learner's needs as a central issue in the design of learning.

This is in line with the application of the English for Specific Purposes (ESP) approach where the learners and their needs are the main considerations in determining the learning process and direction so that the achievement of teaching objectives can work effectively and efficiently (Hutchinson \& Waters, 1987; Robinson, 1991). The main purpose of learning with this approach is to help learners to master English in a short time and appropriately in accordance with their respective fields of knowledge (needs).

Limitations of time to face-to-face in the class often make learning English less effective, especially for classes with varying levels of English. In a higher education climate that demands active learning, English teachers are often difficult to help students whose competence in English is below average to pursue their friends who have adequate competence. As a general compulsory subject, English is only held for one semester. In fact, the target of English language learning on campus is generally quite high, which makes students have sufficient English skills so they can write academic writing in English as an international language.

In an effort to meet the needs of student learning is to utilize as much as possible all the potential that exists. For example, by utilizing the development of information technology utilizing the use of the Internet to collect 
language-based materials based on majors or existing fields of study.

The purpose of this research is to see wether project based content language integrated learning (CLIL) have significant effect on the oral capability of students of science department of the University of Lampung.

\section{Theoretical Framework}

\subsection{Why CLIL?}

In a second or advanced language learning approach, there is a consensus that language must be taught for communication purposes. Therefore, language teaching that is done in a contextual communicative must be supported continuusly to achieve the purpose of language learning is for communication. (Hadley, 2000). Mohan (1986, p.1) even asserted that if there is a principle approach that legitimizes the promotion of language with other subjects, language teaching is the teaching of language can not be combined with other teaching, then this principle is wrong. Mangubhai states that the teaching of languages immersion (combining language with other subjects) is' one of the best learning approaches. (2000, p. 203).

This is supported by Genesee (1994) who suggests that the lesson of the immersion program is the merging of common subjects with language having a more positive effect than separate language learning; Students on immersion-based learning are able to display the same abilities even beyond the abilities of native-speaking children in terms of writing or speech when managed well. While Crandall (1998) asserts that the ability to use language in a special situational context can not be accomplished without integrating the material context with language learning.

In Europe, the incorporation of content with language learning is very popular. Various studies show that CLIL is very effective in improving student achievement. Dalton-Puffer's findings, (2008). Ackerl (2007) and Lasagabaster (2008) demonstrated that students taught through the CLIL program possessed better writing preference than students who were not taught by CLIL. Lasagabaster (2008) emphasizes that CLIL is believed to be able to contribute positively to the preparation for international life, improve learning motivation, improve intercultural communication skills, improve implicit and incidental learning abilities and develop all language skills, especially writing skills.

\subsection{Project Based Project}

Project-based learning is a model of organizing learning in project form. Projects are complex learning tasks based on challenging questions or problems involving learners in designing, problem solving, decision-making or investigative activities, involving self-employed learners for a certain time limit with the goal of producing realistic products to be presented (Jones, Rasmussen, \& Moffitt, 1997; Thomas, Mergendoller, \& Michaelson, 1999).

Stoller (2006) defines Project-based learning as a learning that: has targeted processes and products; Give learners ownership rights to the project; Lasts for a considerable length of time (weeks or months); Integrate skills; Developing students' understanding of a topic through integration of language with other subjects; Collaborate with other students to work independently; Assigning new roles to both students and teachers; Making students produce a qualified final product; Is a reflection of processes and products. Project Based Learning is a learning method that uses problems as a first step in collecting and integrating new knowledge based on experience in real activity. Project-Based Learning is designed to be used on complex issues that students need to investigate and understand.

Project-Based Learning has the following characteristics:

1). students make decisions about a framework;

2). any problems or challenges posed to the students;

3). students design a process to determine the solution to the problem or challenge posed;

4). students are collaboratively responsible for accessing and managing information to solve problems;

5). the evaluation process is carried out continuously;

6). students periodically reflect on the activities that have been carried out;

7). the final product of the learning activity will be evaluated qualitatively; and

8). the learning situation is very tolerant of mistakes and changes.

In its implementation, the project-based learning model has the steps (syntax) that characterize it and distinguish it from other learning models such as discovery learning model and problem based learning model. The steps are; 
(1) determine the basic question; (2) make project design; (3) arrange scheduling; (4) monitoring project progress; (5) assessment of results; (6) evaluation of experience.

The project-based learning model always begins with discovering what the fundamental questions are, which will later become the basis for assigning project assignments to students. Of course, the topic used must also relate to the real world. Furthermore, with the help of lecturers, groups of students will design activities to be performed on their respective projects. The greater the involvement and ideas of the students (groups of students) used in the project, the greater their sense of ownership of the project. Furthermore, lecturers and students determine the time constraints provided in the completion of their project tasks.

\section{Research Methodology}

This research is quantitative and qualitative with quasi experimental principle that is a research design that gives treatment to the subject of research, but the sample is taken purposively, has the main purpose to test whether there is a causal relationship between two or more variables with the data collected from the heterogeneous group. Quantitative data is obtained from the value of students' English proficiency before and after CLIL model application. While the qualitative data obtained from the output of language produced by students during the learning process took place (Hedrick et al., 1993, pp. 58-59). Such research models are also called Experimental-quantitative-interpretive (McKay \& Gass, 2005).

The subject of this research is the students of Mathematics Study Program of The departement of Mathematics and Science, the faculty of teaching and education Universitas Lampung who seat in the English Language Course in odd semester of 2014/2015. The number of students who become subject is 88 people.

\section{Procedures}

This research was implemented for one full semester program of a 2 credit English subject at the mathematics study program. The traditional way of the teaching English within this study program was an integrated English study program in which the lecturers prepare reading materials followed by comprehension questions, completed by practice in vocabulary and grammar. The expriment was done in different way. The new method was giving students opprtunity to explore their field of study using English as a medium of communication. Language form practice was done integratedly within the subject study.

Complete procedure is as follow:

a) A pre test was undertaken to establish the English ability and to be used as the basis to distribute the students within the group. The groups were established comprising 4-5 students in each group.

b) Each group was assigned to do project in the field of mathematics, physics, biology and chemistry and prepare a paper and power point for oral presentation.

c) The groups were given a week for preparation.

d) Group presentation session was undergone; presentation by the member of the group, question and answer session, lecturer's comment on the presentation.

e) All presentations were done in English

\section{Result and Discussion}

(Content Language Integrated Learning (CLIL) is held in the Department of Mathematics and Natural Sciences of Lampung University as the realization of English Language Course which weighs 3 (three) credits. This course is aimed to provide English language skills for students in listening, speaking, reading and writing skills English as a student to develop academic ability in their field of study . Formally English courses consist of 150 minutes face-to-face activities, 150 minutes of structured activity, and 150 minutes of self-help. The total number of meetings for one semester is 16 times including mid-term exam (MTE) and final-term exam (FTE).

Group projects were implemented in eight initial meetings including mid-term exam. Activity details consist of:

A) Group formation was done randomly. Each group consists of 4 or 5 mahasisiwa., so as to produce 8 groups per class.

B) Each group was given different project topics based on the field of science. For example the field of mathematics, the field of physics, the field of biology, and the field of chemistry.

C) The group was tasked with determining project topics, executing projects, preparing written reports, preparing presentations based on discussions undertaken in the project. 


\subsection{Student English Competence}

Student's English competency is obtained through written test provided before and after project-based CLIL implementation. Table 1 below illustrates the students' descriptive statistics.

Tabel 1. Descriptive statistics of students' English competence

\begin{tabular}{lllll}
\hline & $\mathrm{N}$ & Mean & Std. Deviation & Std. Error Mean \\
\hline pretst & 88 & 70,3750 & 6,26303 &, 66764 \\
postst & 88 & 73,5455 & 5,99216 &, 63877 \\
\hline
\end{tabular}

Tabel 1 shows the average score of the students on the pretest of 70.37 with the deviation stand of 8.25 and the mean of the postes 73.64 with the deviation of 5.95. To determine whether there is a significant difference between the mean score of pretest-posttest, a t- test was conducted with the following result

Tabel 2. The result of t-tes on pretest-postest

\begin{tabular}{|c|c|c|c|c|c|c|}
\hline \multicolumn{5}{|c|}{ Test Value $=0$} & \multirow{2}{*}{\multicolumn{2}{|c|}{$\begin{array}{l}95 \% \text { Confidence Interval of the } \\
\text { Difference }\end{array}$}} \\
\hline & & & & & & \\
\hline & $\mathrm{t}$ & Df & Sig. (2-tailed) & Mean Difference & Lower & Upper \\
\hline pretst & 105,408 & 87 &, 000 & 70,37500 & 69,0480 & 71,7020 \\
\hline postst & 115,137 & 87 &, 000 & 73,54545 & 72,2758 & 74,8151 \\
\hline
\end{tabular}

Table 2 shows the comparison between the English students' ability to test students before and after the implementation of the project-based CLIL. T test shows the value of T at the pretest of 106.408 and the postda pda of 116.137. The difference between these values is significant at the 0.001 level. This means that there is a significant difference between the competence or competence of Mathematics students before and after CLIL-based project implementation.

\subsection{Student Performance}

Student performance is the ability of students to express thinkers in English orally. The student's oral skills include aspects: pronuncition grammr, vocabulary, fluency, and comprehensibility. These five aspects are summarized into an overall verbal ability (overall).

Table 3 describes the descriptive statistic of students' oral ability from the initial ability (pretes).

Table 3. Descriptive statistics students' performance at pretest

\begin{tabular}{llllll}
\hline & $\mathrm{N}$ & Minimum & Maximum & Mean & Std. Deviation \\
\hline Vocab & 88 & 2,00 & 4,00 & 2,8864 &, 56082 \\
Pronun & 88 & 2,00 & 4,00 & 2,7557 &, 56728 \\
Gramr & 88 & 2,00 & 4,00 & 2,8466 &, 57913 \\
Fluency & 88 & 2,00 & 4,00 & 2,8466 &, 59383 \\
Compreh & 88 & 2,00 & 4,00 & 3,0909 &, 58006 \\
Overal & 88 & 55,00 & 100,00 & 72,1307 & 10,14648 \\
Valid N (listwise) & 88 & & & & \\
\hline
\end{tabular}

From the result of oral performance test of English, it was found out that for pronunciation aspect, the lowest value was 2 and the highest score was 4 . While the average value $2.76(\mathrm{sd}=0,55)$. For the vocabulary aspect, the lowest score was 2 and the highest score was 4 . The mean value of are $2.88(\mathrm{sd}=0,55)$. For grammar aspect the 
lowest value was 2 and the highest value was 4 with an average value of 2.84 . For the fluency aspect, the highest value was and the highest was 4 with an average value of $2.84 \mathrm{sd}=0.59$. For aspects of comprehensibility (comprehensibility), the lowest score was 2 and the highest score 4 with an average $3.08(\mathrm{sd}=0.58)$.

In total, the average oral ability obtained by mahsiswa is $72,1307, \mathrm{sd}=12,14$. This means that the average oral ability of the Mathematics Student students before being given a CLIL-based learning action project is quite high.

Table 4. describes the descriptive statistic of students' oral ability of the final ability (postest)

Tabel 4. Descriptive statistics performansi Mahasiswa POSTES

\begin{tabular}{llllll}
\hline & $\mathrm{N}$ & Minimum & Maximum & Mean & Std. Deviation \\
\hline vocab2 & 88 & 2,00 & 4,00 & 3,0511 &, 55211 \\
comp2 & 88 & 2,00 & 4,00 & 3,0006 &, 49772 \\
flu2 & 88 & 2,00 & 4,00 & 2,9261 &, 53358 \\
pron2 & 87 & 2,00 & 4,00 & 2,9310 &, 50677 \\
gram2 & 88 & 2,00 & 4,00 & 2,9489 &, 46757 \\
overal2 & 87 & 57,50 & 90,25 & 74,3707 & 6,85023 \\
Valid N (listwise) & 87 & & & & \\
\hline
\end{tabular}

From the result of oral competence test of English students it is known that for the pronunciation aspect the lowest value was 2 and the highest value was 4 , with the average score was $2.93(\mathrm{sd}=0.50)$. For the vocabulary aspect, the lowest score was 2 and the highest score was 4 , the mean score was $3.05(\mathrm{sd}=0.55)$. For the grammar aspect the lowest score was 2 and the highest score was 4 with a mean score of 2.94. For the fluency aspect, the lowest score was 2, the highest score was 4 with a average value of $2.92(\mathrm{sd}=0.53)$. For the aspects of comprehensibility, the lowest score was 2 and the highest score 4 with a mean score of $03.00(\mathrm{sd}=0.49)$.

In total, the average oral ability obtained by the students was $74.37(\mathrm{sd}=6.85)$. This means that the average oral competence of Mathematics students of The Faculty of Teaching and Education, Universitas Lampung before being given a CLIL-based learning action project was quite high.

The following Table 5 is a set of paired t-test between five aspects of students' oral ability on pretest and postes

Tabel 5. Paired Samples Statistics of students' oral performance

\begin{tabular}{llllll}
\hline & & Mean & $\mathrm{N}$ & Std. Deviation & Std. Error Mean \\
\hline Pair 1 & vocab & 2,8864 & 88 &, 56082 &, 05978 \\
& vocab2 & 3,0511 & 88 &, 55211 &, 05886 \\
Pair 2 & pronun & 2,7586 & 88 &, 56989 &, 06110 \\
& pron2 & 2,9310 & 88 &, 50677 &, 05433 \\
Pair 3 & gramr & 2,8466 & 88 &, 57913 &, 06174 \\
& gram2 & 2,9489 & 88 &, 46757 &, 04984 \\
Pair 4 & fluency & 2,8466 & 88 &, 59383 &, 06330 \\
& flu2 & 2,9261 & 88 &, 53358 &, 05688 \\
Pair 5 & compreh & 3,0909 & 88 &, 58006 &, 06183 \\
& comp2 & 3,0006 & 88 &, 49772 &, 05306 \\
Pair 6 & Overal & 72,1552 & 87 & 10,20269 & 1,09384 \\
& overa12 & 74,3707 & 87 & 6,85023 &, 73442 \\
\hline
\end{tabular}




$\begin{array}{lllll}\text { Paired Differences } & \mathrm{t} & \mathrm{df} & \text { Sig. (2-tailed) } \\ \text { Pair 1 } & \text { vocab - vocab2 } & -, 16477 & 87 & , 004 \\ \text { Pair 2 } & \text { pronun - pron2 } & -, 1647 & 87 & , 016 \\ \text { Pair 3 } & \text { gramr - gram2 } & , 10227 & 87 & , 156 \\ \text { Pair 4 } & \text { fluency - flu2 } & -, 07955 & 87 & , 285 \\ \text { Pair 5 } & \text { compreh - comp2 } & , 09034 & 87 & , 208 \\ \text { Pair 6 } & \text { overal - overal2 } & -2,21552 & 87 & , 032\end{array}$

The paired t-test showed that there was a significant difference between the pre test and the postest on vocabulary with a level of significance of .005 . There was a signficant difference between the pre test and post test on pronuncation with a level of significance of .05 . There were no significant differences between the pre test score and the post test score on the aspects of grammar, fluency, and comprehensibility. However, there was signiificant difference between the pre test score and the post test score in overall performance.

\subsection{Observation Results}

Another aspect studied in this research is how students follow all lecture activities through observation of the ability they are involved in group activities completion of their project. The results of the observations are summarized in Table 6 below.

Table 6. Student capability observation

\begin{tabular}{lllllllll}
\hline NO & ACTIVITY & \multicolumn{2}{l}{ PREDICATE } & & & \\
& & $\mathrm{A}$ & & $\mathrm{B}$ & & $\mathrm{C}$ & \\
& & $\mathrm{N}$ & $\%$ & $\mathrm{n}$ & $\%$ & $\mathrm{n}$ & $\%$ \\
\hline 1 & Students' ability in working in group & 68 & 77 & 12 & 13.6 & 8 & 09.1 \\
2 & $\begin{array}{l}\text { Students' ability in discussing in group } \\
3\end{array}$ & $\begin{array}{l}\text { Students' ability in assisting peers who have not mastered the } \\
\text { concept. }\end{array}$ & 58 & 65.9 & 16 & 18.2 & 8 & 09.1 \\
& & 62 & 71.5 & 20 & 22.7 & 6 & 06.8 \\
4. & Responsibility in accomplishing the group task & 56 & 65.7 & 24 & 27.2 & 8 & 09.1 \\
5 & Students' ability in answering the peers' question & 58 & 65.9 & 23 & 26.1 & 7 & 8.0 \\
6 & The students' ability to present the results of discussion & 54 & 61.3 & 25 & 31.0 & 7 & 8.0
\end{tabular}

A.: Very well B.: Well C.: Enough.

The result of the observation showed that the students' ability to work together in the group is 68 students (77\%) can work very well, 12 students $(13,6)$ can do well, and 8 students $(9.1 \%)$ Do it pretty well.

For the students' ability to discuss in group, the result showed 64 students $(72.7 \%)$ able to discuss in group with good teacher, 16 student $(16.2 \%)$ can do well, and 8 students $(9.1 \%)$ did it with pretty good.

For the students' ability to help a group of students who have not mastered the concept, the result shows that 58 students (65.9\%) able to do it with good, 20 students (22.7\%) can do well, and 10 mhsiswa (11.4\%) Do it pretty well.

For the assessment of Responsibility in completing group assignments, the results show that 62 students (71.5\%) can do very well, 20 students $(22.7 \%)$ can do well, and 6 students $(6.8 \%)$ do it well enough.

For assessment the ability of students to answer questions group of friends

The results show 56 students (65.7\%) can do very well, 24 students (27.2\%) can do well, and 8 students (9.1\%) do pretty well. 
For Assessment of Students' Resilience presents the results of the discussion

The results show 58 students (65.9\%) can do very well, 23 students (26.1\%) can do well, and 7 students (8\%) do it well enough.

The students 'ability to answer the lecturers' questions showed that 54 students $(61.3 \%)$ did very well, 25 students (31\%) did well, and 7 students (8\%) did well.

\subsection{Student Perceptions}

To find out how students' perceptions of English learning activities using CLIL-based projects, students are asked to respond in two ways, first by completing the questionnaire and answering 5 questions in the form of a complete answer. Answers to the mahasiswa are summarized in Table 7, whereas written responses are described separately.

Tabel 7. Questionnaire of student perceptions on learning LEARNING ENGLISH LEARNING USING CLIL AND PROJECT BASED LEARNING

\begin{tabular}{|c|c|c|c|}
\hline \multirow[t]{2}{*}{ No } & \multirow[t]{2}{*}{ Questions } & \multicolumn{2}{|l|}{ Opinion } \\
\hline & & YES & NO \\
\hline 1 & Is the learning through CLIL Project Based Learning easier? & $80 / 90.9 \%$ & $8 / 9.1 \%$ \\
\hline 2 & Does the learning through project based CLIL more motivate to learn & $82 / 93 \%$ & $6 / 7 \%$ \\
\hline 3 & Is the learning through project based CLIL more enjoyable & $70 / 79 \%$ & $18 / 21 \%$ \\
\hline 4 & $\begin{array}{l}\text { Do you think autonomy learning by learning through model CLIL } \\
\text { Project Based Learning? }\end{array}$ & $70 / 79 \%$ & $18 / 21 \%$ \\
\hline 5 & $\begin{array}{l}\text { Do you think learning through CLIL Project Based Learning more } \\
\text { active in the teaching learning process? }\end{array}$ & $74 / 84 \%$ & $14 / 26 \%$ \\
\hline 6 & $\begin{array}{l}\text { Do you think learning through CLIL Project Based Learning can use } \\
\text { your learning time more effectively? }\end{array}$ & $72 / 82 \%$ & $16 / 18 \%$ \\
\hline 7 & $\begin{array}{l}\text { Do you think learning through CLIL Project Based Learning can raise } \\
\text { your interest in learning? }\end{array}$ & $82 / 93 \%$ & $6 / 7 \%$ \\
\hline 8 & $\begin{array}{l}\text { Do you think learning through CLIL Project Based Learning can raise } \\
\text { your English mastery? }\end{array}$ & $74 / 84 \%$ & $14 / 26 \%$ \\
\hline 9 & $\begin{array}{l}\text { Do you think learning through CLIL Project Based Learning can raise } \\
\text { your understanding of English }\end{array}$ & $74 / 84 \%$ & $14 / 26 \%$ \\
\hline 10 & $\begin{array}{l}\text { Do you think learning through CLIL Project Based Learning should } \\
\text { be applied to other subjects? }\end{array}$ & $82 / 93 \%$ & $6 / 7 \%$ \\
\hline
\end{tabular}

\section{Discussion}

From the research results can be known things as follows: CLIL program-based project for the English language course in Mathematics study program the faculty of teaching and education of the University of Lampung can run well. This is evident from the implementation of the whole program activities from the implementation of the formation of groups, students work in groups to finish the project well. Group presentation activities in English, personal presentations and student responses to all activities. This is in line with the opinion of Mangubhai (2000) who states that the teaching of language immersion (combining language with other subjects) is' one of the best learning approaches. (2000, p. 203).

Another thing gained from this research is product oriented learning and process oriented learning Product-oriented learning is generally based on psychological theories Behaviorism, based on Pavlov's classical experiments, Thorndike's work on studying, and Watson and Rayner's studies applying Pavlov's principles to psychological disorders. And Skinner's work is considered an important reference in this field and its application in education (Joyce, Weil, \& Calhoun, 2000: 318).

In language teaching, the learning model in this group generally has characteristics that Krashen (1981) calls "learning", such as bound by formal procedures, product-oriented / appearance, and sorted by grammatical 
sequence. The role of teachers is very dominant in determining the direction and procedure of learning. This role is particularly prominent in the tubian and substitution activities that are most prevalent in these approaches. Among the most popular approaches in this group is the Audiolingual Approach.

Approach to speech is rooted from two schools of thought that are parallel in the field of psychology and linguistics. In the field of psychology, this approach is rooted in behaviorism and neo-behaviorism, whereas in the linguistic field this approach is rooted in structural or descriptive flow (Hadley, 2001). The learning methods resulted from this approach are given the same name, the audio method, which is also known by the following names: Functional Skills, New Key Information, and American Methods (Benseler \& Schulz, 1980).

Unlike the learning model-learning model in product-oriented larning, learning-model in this group is rooted in the thoughts of social theorists, which emphasizes the social nature of human beings, the way humans learn social behavior and the way social interaction serves to strengthen the success of academic learning (Joyce, Weil, $\&$ Calhoun, 2000). In practice, these principles form the development of cooperative learning societies. The assumptions underlying the practice have been summarized by Joyce, Weil, and Calhoun (2000), namely:

1) The synergy generated in a cooperative setting produces a stronger motivation than that produced by individualistic and competitive environments. Hence, an integrative social group is more than a collection of parts of it. The sense of being connected produces positive energy.

2) Cooperative group members learn from each other. Each student gets more help than in a yielding order solitude.

3) Interaction between members produces cognitive complexity in addition to social complexity, creating more intellectual activity that supports learning rather than self-study.

4) Cooperation enhances positive feelings toward others, reduces alienation and loneliness, builds relationships, and provides solid views of others.

5) Cooperation improves self-image not only through increased learning but also through a sense of being appreciated and cared for by others in the environment.

6) Students can respond to experience in performing tasks which requires cooperation through the improvement of their work skills together. In other words, the greater the students are given the opportunity to work together, the better their skills in working together. This ability helps their general social skills.

7) Students, including elementary school students, can learn from practice for improving their cooperation skills.

\section{Conclusion}

From the description of results and discussion, it can be concluded that:

a) There is a significant influence on the project-based Content Language Integrated Learning approach to the fluency and accuracy of English students of the Department of Education, Faculty of Mathematics and Natural Sciences, University of Lampung. This is evident from the significant differences between the ability of students before and after following the English language learning through project-based Content Language Integrated Learning.

b). Students' responses to English learning before and after project-based Content Language Integrated Learning are very positive. This is evident from the responses of students to the questionnaire (questionnaire) given or written responses of students in the form of essays.

\section{References}

Ackerl. (2007). Lexico-grammar in the essays of CLIL and non- CLIL students: Error analysis of written production. Vienna English Working Papers, 16(3), 6-12.

Benseler, D. P., \& Schulz, R. E. (1980) Methodological Trends in College Foreign Language Instruction. The Modern Language Journal, 64(1). https://doi.org/10.1111/j.1540-4781.1980.tb05172.x

Crandall, J. (1998). Collaborate and Cooperate: Teacher Education for Integrating Language and Content Instruction. Forum, 36(1).

Dalton-Puffer, C. (2008). Outcomes and processes in Content and Language Integrated Learning (CLIL): current research from Europe. In W. Delanoy, \& L. Volkmann (Eds.), Future Perspectives for English Language Teaching (pp. 139-157). Heidelberg: Carl Winteer.

Faculty of Teaching and Education (FKIP) Universitas Lampung. (2016). Student Hand Book. Universitas Lampung. 
Genesee, F. (1994). Integrating Language and Content: Lessons from Immersion. McGill University. National Center For Research On Cultural Diversity and Second Language Learning.

Hadley, A. O. (2001). Teaching Language in Context Third Edition. Boston, MA: Heinle and Heinle Thomson Learning.

Hedrick, T. E., Bickman, L., \& Rog, D. J. (1993). Applied research design: a practical guide. Sage, Newbury Park, California, USA. https://doi.org/10.1111/j.1540-4781.1980.tb05172.x

Hutchinson, T., \& Waters, A. (1987). English for Specific Purposes: A Learner-centered Approach. Cambridge University Press. https://doi.org/10.1017/cbo9780511733031

Jones, G. (1990). ESP textbooks: Do they really exist? English for Specific Purposes, 9, 89-93. https://doi.org/10.1016/0889-4906(90)90030-G

Joyce, B., Weil, M. \& Calhoun, E. (2000). Models of Teaching Sixth Edition. Boston: Allyn and Bacon.

Krashen, S. D. (1981). Second language acquisition and second language learning. New York: Pergamon.

Krashen, S. D. (1982). Principles and Practices in Second Language Acquisition. Oxford: Pergamon.

Lal, P., \& Mangubhai, F. (2000). What learning strategies do ESL learners in Fiji use? - An exploratory study. Directions, 22 (1), 53-69.

Lasagabaster, D. (2008). Foreign language competence in content and language integrated courses. The Open Applied Linguistics Journal, 1, 31-42. https://doi.org/10.2174/1874913500801010030

Lasagabaster, D. (2011). English achievement and student motivation in CLIL and EFL settings. Innovation in Language Learning and Teaching, 5(1), 3-18. https://doi.org/10.1080/17501229.2010.519030

McKey, A., \& Susan, M. G. (2011). Research Methods in Second Language Acquisition: A Practical Guide. Wiley-Blackwell.

Mohan, B. (1986). Language and Content. Addison-Wesley.

Watson, J. B., \& Rayner, R. (1920). Conditioned emotional reaction. Journal of Experimental Psychology, 3, 1-14. https://doi.org/10.1037/h0069608

\section{Copyrights}

Copyright for this article is retained by the author(s), with first publication rights granted to the journal.

This is an open-access article distributed under the terms and conditions of the Creative Commons Attribution license (http://creativecommons.org/licenses/by/4.0/). 